\title{
Evaluating the diet of children at increased risk for type 1 diabetes: first results from the TEENDIAB study
}

\author{
Katharina Susanne Weber 1,2, Jennifer Raab ${ }^{1,2}$, Florian Haupt ${ }^{1,2}$, Bärbel Aschemeier ${ }^{3}$, \\ Anja Wosch ${ }^{1}$, Christiane Ried ${ }^{1}$, Olga Kordonouri ${ }^{3}$, Anette-Gabriele Ziegler ${ }^{1,2}$ and \\ Christiane Winkler ${ }^{1,2, *,} \dagger$ \\ 'Institute of Diabetes Research, Helmholtz Zentrum München, and Forschergruppe Diabetes, Klinikum rechts der \\ Isar, Technische Universität München, Munich, Germany: ${ }^{2}$ Forschergruppe Diabetes e.V., Neuherberg, \\ Germany: ${ }^{3}$ Kinder- und Jugendkrankenhaus auf der Bult, Hannover, Germany
}

Submitted 28 March 2013: Final revision received 22 November 2013: Accepted 26 November 2013: First published online 2 January 2014

\begin{abstract}
Objective: The development of type 1 diabetes (T1D) is potentially influenced by nutrition. The aim of our study was to assess food and nutrient intakes of children at increased risk of T1D.

Design: Dietary intake of the last 4 weeks was assessed using a diet history interview. The daily nutrient and food intakes were compared with the German Dietary Reference Intakes, the Optimized Mixed Diet recommendations and those of a representative sample of children from the EsKiMo study.

Setting: Children included in the analysis participated in the prospective TEENDIAB study.

Subjects: First-degree relatives of people with T1D ( $n$ 268), aged 8-12 years.

Results: The TEENDIAB children consumed $52.0 \%$ of their total energy from carbohydrates, $32 \cdot 6 \%$ from fat and $14 \cdot 3 \%$ from protein. Compared with the reference values, their intake was lowest for folate at $61.3 \%$ of the reference, for iodine at $58.1 \%$ and for vitamin $\mathrm{D}$ at $8.9 \%$, and exceeded the reference for vitamin $\mathrm{K}$ about 5 -fold, for $\mathrm{Na}$ about $3 \cdot 5$-fold and for protein about $1 \cdot 5$-fold. Their nutrient intakes were similar to those of a control cohort without increased T1D risk. The consumption of non-desirable food groups (meat products, sweets/snacks) was above the recommendations and the consumption of desirable food groups (fruits, vegetables, carbohydrate-rich foods) was below the recommendations.

Conclusions: The TEENDIAB children had intakes considerably below the recommendations for vitamin $\mathrm{D}$, iodine, folate and plant-based foods, and intakes above for vitamin $\mathrm{K}, \mathrm{Na}$, protein, meat products and sweets/snacks. They showed similar dietary patterns to non-risk children.
\end{abstract}

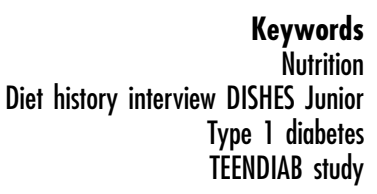

Type 1 diabetes (T1D), an autoimmune disease which requires lifelong insulin administration, affects about 20 to 35 million people worldwide and has a peak incidence in childhood and adolescence ${ }^{(1)}$. The overall incidence of T1D is increasing rapidly but the exact nature of the factors contributing to and triggering the development of T1D is still extensively discussed and not yet known ${ }^{(1)}$, especially for the disease manifestation during puberty ${ }^{(2)}$. Already accepted is the interaction of genetic and environmental factors and the polygenic character of T1D susceptibility which triggers autoimmunity in genetically predisposed subjects ${ }^{(3)}$.

$\dagger$ Correspondence address: Institute of Diabetes Research, Helmholtz Zentrum München, Ingolstaedter Landstr. 1, 85764 Neuherberg,Germany.
The environmental factors possibly involved in the disease are viral infections, diet, vaccinations and psychosocial factors $^{(1,3)}$. There is evidence from animal and human research which indicates an association between the intake of certain foods as well as nutrients and the development of $\mathrm{T}^{(4)}{ }^{(4)}$. Three prospective birth cohort studies revealed that early introduction of gluten, other cereals, fruit and berry juices as well as cow's milk increased the risk of $\beta$-cell autoimmunity ${ }^{(5-7)}$. However, there has been still no dietary component identified as a clear risk factor ${ }^{(6,8)}$. As many nutritional factors probably work in an age-dependent manner, the findings for early infancy might not be transferable to later childhood or $\operatorname{adulthood}^{(4,6)}$

Data for the correlation of diet and incidence of autoimmunity and T1D for children and adolescents are 
sparse and often based only on single studies. A high intake of fruits, vegetables ${ }^{(4)}$, cow's milk ${ }^{(4,9)}$, meat, dairy products $^{(10)}$, coffee and tea ${ }^{(9)}$, as well as total $\mathrm{fat}^{(4)}$, protein and carbohydrates ${ }^{(11)}$, was hypothesized to increase the risk of T1D in children and adolescents. Additionally, an increased risk of T1D was associated with a higher energy intake and a higher consumption of bread and carbohydrates, especially in the form of disaccharides and sucrose, one year before the manifestation of $\mathrm{T}_{1} \mathrm{D}^{(12)}$. A high consumption of cereals ${ }^{(10)}$ as well as a high intake of vitamin $\mathrm{D}$, vitamin $\mathrm{E}$ and $\mathrm{Zn}^{(9)}$ was found to be protective. However, there is a great necessity to confirm these correlations in large prospective cohort studies. Furthermore, an evaluation of the dietary intake of adolescents at increased risk of T1D in terms of adherence to current recommendations is missing.

The TEENDIAB study, a cohort study in children with a familial risk of T1D, was set up to increase the knowledge on genetic and environmental factors influencing the development of islet autoimmunity and T1D during puberty, as they are hypothesized to differ from those during infancy ${ }^{(2)}$. In the present study we assessed the dietary intake of the TEENDIAB children, and measured it against the German Dietary Reference Intakes on the nutrient level ${ }^{(13)}$ and against the Optimized Mixed Diet recommendations developed by the Research Institute of Child Nutrition in Dortmund ${ }^{(14,15)}$ on the food level. Furthermore, we compared the intake data of the TEENDIAB children with those of a representative sample of children aged 12 years from the EsKiMo study, the nutrition module of KiGGS, the German Health Interview and Examination Survey of Children and Adolescents ${ }^{(16)}$. With these analyses we aimed to characterize the diet of children at increased risk of T1D, to investigate compliance with current reference data and recommendations, and to examine whether there are differences in dietary behaviour between at-risk and non-risk children.

\section{Methods}

\section{Study population}

Dietary intake was assessed in children participating in the TEENDIAB study. The TEENDIAB study is a prospective, observational cohort study. Subjects are recruited through a network of paediatricians which was generated for recruitment into former studies. Additionally, direct communication to affected families is facilitated by publications within a nationwide diabetes information network. Children can be included in the TEENDIAB study if they are between 8 and 12 years old, if they are resident in Germany and if they have at least one first-degree relative diagnosed with T1D. The subjects are followed up to the age of 18 years to investigate the period of puberty and adolescence in the natural course of T1D development, as previously described in detail ${ }^{(2)}$.
The study was conducted according to the guidelines laid down in the Declaration of Helsinki and all procedures involving human subjects were approved by the ethical committee of the Technical University Munich (No. 2149/08) and Medizinische Hochschule Hannover (No. 5644). Written informed consent was obtained from all subjects.

For the current analysis, the diet of all children enrolled in the TEENDIAB study between February 2009 and January 2012 was assessed. In total, there were nutritional data of 270 participants aged 8-12 years available. The data of two children were incomplete and had to be excluded, which resulted in 268 participants remaining for examination.

\section{Antbropometric and sociodemographic data}

A physical examination was performed at study entry to measure weight and height of each child by a trained staff member. Weight, height and BMI were adjusted for gender and age at examination and were expressed as a percentile against national reference data. Children below the 10th percentile were classified as underweight, children between the 10th and 90th percentiles as normal weight and children equal to or above the 90th percentile as overweight ${ }^{(17)}$.

Sociodemographic data were assessed using a demographic questionnaire at study entry. Based on the school education of the parents and the net income of the family, each parent was assigned to an educational and a net income score. Both scores ranged from 1 to 6 points with higher points for higher educational level and net income. These two scores were summed up individually for each parent. The higher one of both scores was assigned to the child. Based on this, the children were classified into one of three socio-economic classes. Children with $2-5$ points belonged to the lower class, those with 10-12 points to the upper class and the ones in between to the middle class.

\section{Dietary evaluation using the diet bistory interview DISHES Junior}

In the TEENDIAB study, diet was assessed using the modified computer-assisted Diet Interview Software for Health Examination Studies Junior (DISHES Junior; Robert Koch Institute, Berlin, Germany). This interview and the software had been updated and adapted for dietary assessment in children and adolescents for the EsKiMo study ${ }^{(16,18,19)}$. In the TEENDIAB study, the standardized computerized questionnaire was performed in an interview style on site and in person by trained study nurses. It retrospectively assessed the consumed frequency, type and quantity of foods and beverages of the last 4 weeks $^{(20)}$. The portion size estimation was assisted by household measures consisting of cups, spoons, plates and bowls, and by a picture book which comprised colour photographs of foods in different 
portion sizes ${ }^{(20,21)}$. The interview software of DISHES Junior is linked to the German Nutrient Database, Version II·3 (Bundeslebensmittelschlüssel, BLS; Max Rubner Institut, Karlsruhe, Germany), which allows analysis of the average daily intakes of energy, macronutrients and micronutrients $^{(2,20)}$.

The nutritional data of the TEENDIAB children were compared with the German Dietary Reference Intakes on the nutrient level and with the Optimized Mixed Diet recommendations on the food level. The German Dietary Reference Intakes were elaborated by the German Nutrition Society, the Austrian Nutrition Society, the Swiss Society for Nutritional Research and the Swiss Food Association. They provide nutrient-based reference values for the nutrient requirements of defined groups of the healthy population ${ }^{(13)}$. The Optimized Mixed Diet recommendations were established by the Research Institute of Child Nutrition in Dortmund. It provides food-based recommendations for a child-specific diet by implementing the German Dietary Reference Intakes and by additionally applying the current recommendations for the prevention of diet-related diseases. The foods and beverages are grouped into eleven food groups ${ }^{(15,22)}$ and furthermore classified into three categories: (i) 'plant foods and beverages', which should be consumed amply; (ii) 'animal foods', with a moderate consumption; and (iii) 'high-fat, high-sugar foods', which are recommended only sparingly ${ }^{(14,22)}$. For the current analysis the separation between the two food groups 'potatoes' and 'bread, grains, cereals' was not completely possible. Therefore, both groups were combined into the new group 'carbohydrate-rich foods'. Furthermore, we compared the nutrient intakes of the TEENDIAB children with those of a representative sample of children from the EsKiMo study. The EsKiMo study includes a sub-sample of 2506 participants of the KiGGS study and assessed the diet of children aged 6-11 years using a $3 \mathrm{~d}$ estimated food record as well as the diet of the children aged 12-17 years using DISHES Junior ${ }^{(16)}$. In order to ensure a comparison of intake data assessed with the same method in both cohorts, we used a sub-sample of children aged 12 years from the EsKiMo study.

For evaluation of the energy and nutrient intakes of the TEENDIAB children, the intake data were expressed as percentage values of the German Dietary Reference Intakes and as percentage values of the EsKiMo intake data. These percentage values were calculated on an individual level for boys, girls and age groups. On the food level, the amounts consumed in each food group were compared with the Optimized Mixed Diet recommendations, which are given as proportions of the food groups by weight (\%) as the absolute amounts of intake vary with age, sex and energy requirement ${ }^{(14)}$. Therefore, we recalculated the absolute intake data of the children as percentages of the total weight consumed.

\section{Statistical analysis}

All statistical analyses were performed using the statistical software package IBM SPSS Statistics 20 for Windows 7. The nutrient and food intake data were not normally distributed, thus are expressed as median and interquartile range (IQR; 25 th percentile $\left(\mathrm{P}_{25}\right)-75$ th percentile $\left(\mathrm{P}_{75}\right)$ ). The Wilcoxon signed-rank test was used to test differences between the TEENDIAB nutrient and food intake data and the respective references values, recommendations as well as the intake data of the EsKiMo cohort. We used Bonferroni's correction method to adjust for multiple comparisons. We considered only $P$ values $<0 \cdot 05 / 26=0 \cdot 0019$ as significant in the analysis regarding comparison with the German Dietary Reference Intakes, $P$ values $<0 \cdot 05 / 34=0 \cdot 0015$ as significant in the analysis regarding comparison with the EsKiMo data, and $P$ values $<0 \cdot 05 / 10=0 \cdot 005$ were considered to be significant in the analysis regarding the Optimized Mixed Diet recommendations.

\section{Results}

\section{Characterization of the study population}

All 268 children, of whom 53\% were male, were of Caucasian ethnicity with a median age of $10 \cdot 6$ years (IQR: $9 \cdot 4-11.6$ years). Only 3\% of the children were not of German nationality. The percentage of overweight and obese children was with $11 \%$ somewhat lower within the TEENDIAB cohort compared with the representative sample of German children and adolescents from the KiGGS study with about $15-17 \%$ of overweight and obese children ${ }^{(23)}$. The median monthly family net income of the TEENDIAB families was $3000 €$ (IQR: 2000-4000 €; data available only for 230 children). When grouped into socio-economic classes only $3 \%$ of all participants were ranked into the lower class. The majority of all children, 73\%, had a parent affected with T1D, 23\% had a sibling with T1D and $4 \%$ of the children had more than one first-degree relative with T1D (Table 1).

\section{Macronutrient intake data as a percentage of total energy intake}

The children consumed $52 \cdot 0 \%$ of their energy from carbohydrates $(23.9 \%$ from mono- and disaccharides and $27 \cdot 7 \%$ from polysaccharides), $32 \cdot 6 \%$ from fat $(13.9 \%$ from SFA, $11 \cdot 3 \%$ from MUFA, $4 \cdot 6 \%$ from PUFA, and the rest from glycerol and lipoids) and $14 \cdot 3 \%$ from protein. In line with expectations, dietary fibre only made up $1 \cdot 1 \%$ of the total energy intake (Fig. 1).

\section{Dietary intake data measured against the German Dietary Reference Intakes}

The TEENDIAB children had a significantly higher energy intake compared with the German Dietary Reference Intakes $(103 \cdot 6 \%$ of the reference (IQR: $87 \cdot 5-125 \cdot 0 \%$; 
$P<0 \cdot 001))$ and consumed significantly more protein (244.5\% of the reference (IQR: $193 \cdot 8-309 \cdot 4 \% ; P<0 \cdot 001)$ ), dietary fibre $(111 \cdot 3 \%$ of the reference (IQR: $93 \cdot 6-141 \cdot 7 \%$;

Table 1 Characteristics of the TEENDIAB children included in the present analysis, Germany, February 2009-January 2012

\begin{tabular}{lrr}
\hline Characteristic & $n$ & $\%$ \\
\hline Age & & \\
8 years & 44 & 16 \\
9 years & 60 & 22 \\
10 years & 50 & 19 \\
11 years & 94 & 35 \\
12 years & 20 & 7 \\
Females & 126 & 47 \\
German nationality & 258 & 96 \\
Weight status* & & \\
Underweight† & 34 & 13 \\
Normal weightł & 205 & 76 \\
Overweight§ & 29 & 11 \\
Socio-economic status\| & & \\
Lower class & 7 & 3 \\
Middle class & 129 & 48 \\
$\quad$ Upper class & 132 & 49 \\
First-degree relative affected with T1D & & \\
Parent affected with T1D & 197 & 73 \\
Sibling affected with T1D & 61 & 23 \\
Multiple affected first-degree relatives & 10 & 4 \\
\hline
\end{tabular}

T1D, type 1 diabetes.

$n 268$ for all except German nationality ( $n 266)$.

*BMI was adjusted for gender and age at examination and expressed as a percentile against national reference data ${ }^{(17)}$.

tBelow the 10th age- and gender-specific percentile of the reference population $^{(31)}$.

fBetween the 10th and 90th percentile of the reference population ${ }^{(31)}$.

$\S$ Equal to or above the 90th percentile of the reference population ${ }^{(31)}$.

ISocio-economic classes (lower, middle, upper class) calculated on the basis of the school education of the parents and the monthly net income of the family.
$P<0 \cdot 001))$ and cholesterol (186.2\% of the reference (IQR: $152 \cdot 4-223 \cdot 1 \% ; P<0 \cdot 001)$ ). Within the group of micronutrients, the children had intakes above the recommended values for most of the minerals ( $\mathrm{Ca}, \mathrm{P}, \mathrm{Fe}, \mathrm{Zn}$, $\mathrm{K}, \mathrm{Mg}$ ) and vitamins (A, C and B-complex). Their intake was highest for vitamin $\mathrm{K}$ at $803.4 \%$ of the reference (IQR: $633 \cdot 4-1080 \cdot 4 \% ; P<0.001)$ as well as for $\mathrm{Na}$ at $546 \cdot 4 \%$ of the reference value (IQR: 449.2-659.3\%; $P<0.001$ ), and lowest for vitamin D at $8.9 \%$ of the reference (IQR: $5 \cdot 8-13.2 \% ; P<0 \cdot 001)$, iodine at $58.1 \%$ of the reference value (IQR: $46 \cdot 1-73 \cdot 3 \% ; P<0 \cdot 001$ ) and folate at $61.3 \%$ of the reference (IQR: $47 \cdot 9-77 \cdot 5 \% ; P<0 \cdot 001$ ). Of all micronutrients, only vitamin $\mathrm{E}$ at $103.9 \%$ of the reference (IQR: $78 \cdot 2-133 \cdot 7 \%$ ) and pantothenic acid at $97 \cdot 3 \%$ of the reference (IQR: 79.9-123.5\%) were not significantly different from the recommended values (Table 2 ).

\section{Dietary intake data of the TEENDIAB children compared with a representative sample}

The comparison of the sub-sample of the TEENDIAB study consisting of twenty children aged 12 years with that of the EsKiMo cohort assessed with the same method showed very similar energy and nutrient intakes. There was no significant difference for the intake of any of the analysed nutrients between both cohorts (Table 2).

\section{Food consumption data measured against the Optimized Mixed Diet recommendations}

The food intake data of the TEENDIAB children were additionally compared with the Optimized Mixed Diet recommendations. The amounts of beverages, meat and

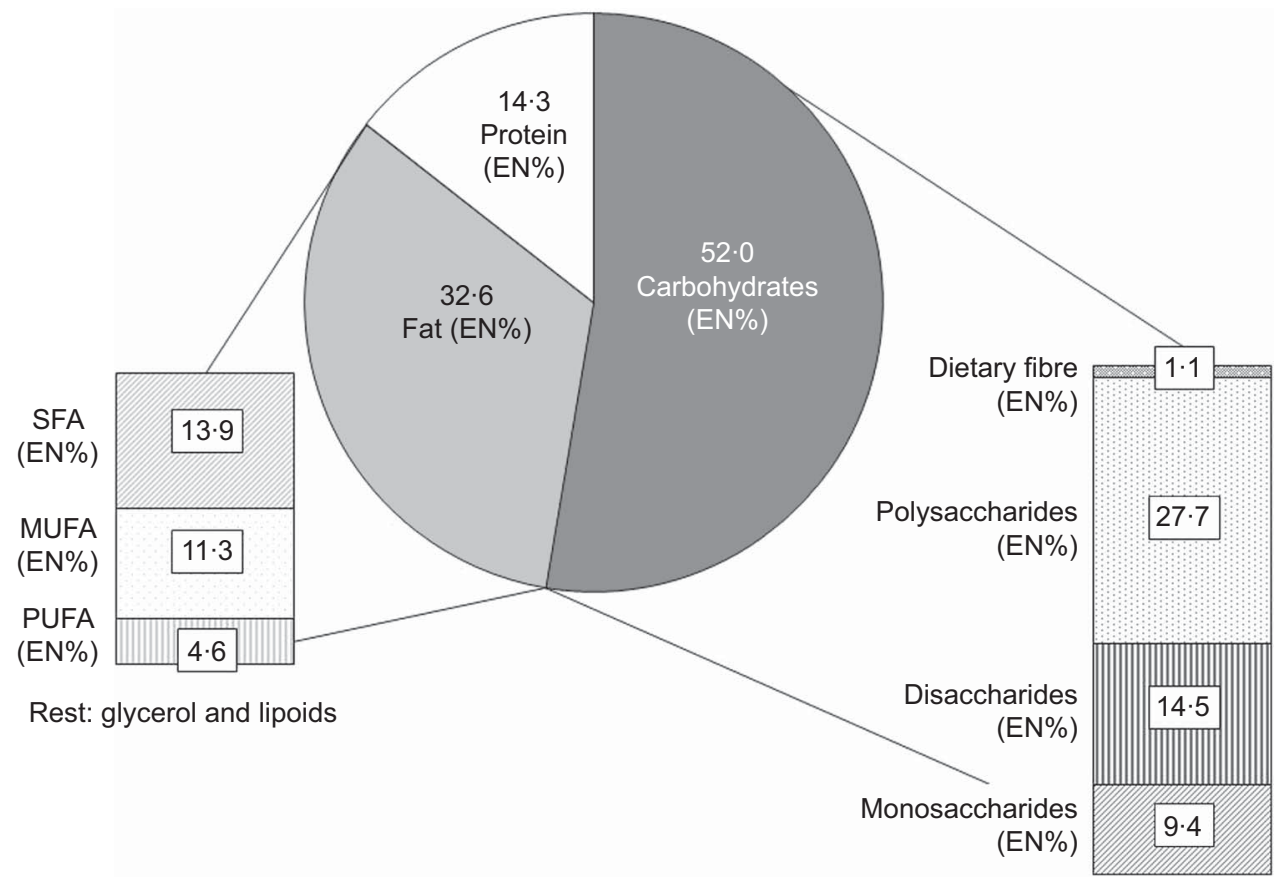

Fig. 1 Macronutrient intakes as a percentage of total energy intake (EN\%) among the TEENDIAB children ( $n$ 268), Germany, February 2009-January 2012 
Table 2 Daily energy and nutrient intakes, percentage of the German Dietary Reference Intakes and comparison against the EsKiMo intake data: TEENDIAB children, Germany, February 2009-January 2012

\begin{tabular}{|c|c|c|c|c|c|c|c|c|c|}
\hline \multirow[b]{3}{*}{ Nutrient } & \multicolumn{9}{|c|}{ Nutrient intake data } \\
\hline & \multicolumn{3}{|c|}{$\begin{array}{l}\text { Absolute amount } \\
\text { (n 268, 8-12 years) }\end{array}$} & \multicolumn{3}{|c|}{$\begin{array}{l}\% \text { of German Dietary Reference Intakes* } \\
\text { ( } n \text { 268, 8-12 years) }\end{array}$} & \multicolumn{3}{|c|}{$\begin{array}{l}\% \text { of EsKiMo subjectst } \\
(n 20,12 \text { years })\end{array}$} \\
\hline & Median & $\mathrm{P}_{25}$ & $\mathrm{P}_{75}$ & Median & $\mathrm{P}_{25}$ & $\mathrm{P}_{75}$ & Median & $\mathrm{P}_{25}$ & $\mathrm{P}_{75}$ \\
\hline Energy (kJ) & $8931 \cdot 2$ & $7353 \cdot 0$ & $10732 \cdot 0$ & $103 \cdot 6 \ddagger$ & $87 \cdot 5$ & $125 \cdot 0$ & $102 \cdot 4$ & $73 \cdot 6$ & $115 \cdot 1$ \\
\hline Protein $(\mathrm{g})$ & $72 \cdot 4$ & $60 \cdot 8$ & $90 \cdot 2$ & $244 \cdot 5 \ddagger$ & $193 \cdot 8$ & $309 \cdot 4$ & $106 \cdot 0$ & $87 \cdot 4$ & $132 \cdot 1$ \\
\hline Fat $(\mathrm{g})$ & $77 \cdot 8$ & $62 \cdot 4$ & $96 \cdot 6$ & - & - & - & $89 \cdot 5$ & $72 \cdot 8$ & $118 \cdot 6$ \\
\hline SFA (g) & $34 \cdot 0$ & $25 \cdot 7$ & $41 \cdot 0$ & - & - & - & $95 \cdot 2$ & $75 \cdot 2$ & $116 \cdot 2$ \\
\hline MUFA (g) & $27 \cdot 0$ & $22 \cdot 4$ & $34 \cdot 4$ & - & - & - & $85 \cdot 9$ & $72 \cdot 9$ & $109 \cdot 0$ \\
\hline PUFA (g) & $11 \cdot 2$ & $8 \cdot 6$ & $14 \cdot 6$ & - & - & - & $99 \cdot 4$ & $72 \cdot 8$ & $137 \cdot 4$ \\
\hline Carbohydrates (g) & $273 \cdot \overline{7}$ & $214 \cdot 5$ & $329 \cdot 5$ & - & - & - & $94 \cdot 2$ & $72 \cdot 5$ & $119 \cdot 9$ \\
\hline Mono-/disaccharides (g) & $146 \cdot 5$ & $87 \cdot 1$ & $190 \cdot 8$ & - & - & - & $97 \cdot 0$ & $66 \cdot 0$ & $143 \cdot 2$ \\
\hline Polysaccharides (g) & $0 \cdot 1$ & $0 \cdot 1$ & $0 \cdot 1$ & - & - & - & $99 \cdot 7$ & $83 \cdot 2$ & $139 \cdot 7$ \\
\hline Dietary fibre $(\mathrm{g})$ & $24 \cdot 7$ & $18 \cdot 8$ & $30 \cdot 8$ & $111 \cdot 3 \ddagger$ & $93 \cdot 6$ & $141 \cdot 7$ & $108 \cdot 4$ & $94 \cdot 9$ & $136 \cdot 9$ \\
\hline Water (g) & $2325 \cdot 9$ & $1839 \cdot 1$ & $2828 \cdot 3$ & $115 \cdot 2 \ddagger$ & $92 \cdot 5$ & $141 \cdot 5$ & $111 \cdot 9$ & $81 \cdot 1$ & $133 \cdot 6$ \\
\hline Cholesterol (mg) & $312 \cdot 6$ & $230 \cdot 9$ & $402 \cdot 3$ & $186 \cdot 2 \ddagger$ & $152 \cdot 4$ & $223 \cdot 1$ & $95 \cdot 6$ & $77 \cdot 5$ & $147 \cdot 1$ \\
\hline $\mathrm{Na}(\mathrm{mg})$ & $2689 \cdot 9$ & $2215 \cdot 8$ & $3207 \cdot 6$ & $546 \cdot 4 \ddagger$ & $449 \cdot 2$ & $659 \cdot 3$ & $93 \cdot 9$ & $79 \cdot 7$ & $122 \cdot 4$ \\
\hline $\mathrm{K}(\mathrm{mg})$ & $3123 \cdot 0$ & $2569 \cdot 2$ & $3743 \cdot 0$ & $188 \cdot 4 \ddagger$ & $155 \cdot 6$ & $227 \cdot 5$ & $104 \cdot 3$ & $97 \cdot 2$ & $118 \cdot 5$ \\
\hline $\mathrm{Ca}(\mathrm{mg})$ & $1094 \cdot 0$ & $858 \cdot 4$ & $1383 \cdot 4$ & $107 \cdot 5 \ddagger$ & 86.9 & $135 \cdot 9$ & $102 \cdot 8$ & $84 \cdot 7$ & $131 \cdot 8$ \\
\hline $\mathrm{Mg}(\mathrm{mg})$ & $411 \cdot 5$ & $334 \cdot 7$ & $491 \cdot 9$ & $200 \cdot 4 \ddagger$ & $158 \cdot 7$ & $250 \cdot 4$ & $113 \cdot 4$ & $87 \cdot 3$ & $131 \cdot 4$ \\
\hline $\mathrm{P}(\mathrm{mg})$ & $1308 \cdot 8$ & $1099 \cdot 5$ & $1648 \cdot 3$ & $127 \cdot 9 \ddagger$ & $97 \cdot 2$ & $162 \cdot 0$ & $109 \cdot 9$ & $90 \cdot 1$ & $134 \cdot 2$ \\
\hline $\mathrm{Fe}(\mathrm{mg})$ & $13 \cdot 9$ & $11 \cdot 1$ & $17 \cdot 5$ & $120 \cdot 3 \ddagger$ & $97 \cdot 7$ & $153 \cdot 1$ & $104 \cdot 5$ & $81 \cdot 6$ & $130 \cdot 8$ \\
\hline $\mathrm{Zn}(\mathrm{mg})$ & $11 \cdot 1$ & $9 \cdot 3$ & $13 \cdot 9$ & $151 \cdot 0 \ddagger$ & $123 \cdot 2$ & $178 \cdot 4$ & $112 \cdot 8$ & $88 \cdot 8$ & $137 \cdot 2$ \\
\hline Iodine $(\mu \mathrm{g})$ & $95 \cdot 2$ & $75 \cdot 7$ & $120 \cdot 5$ & $58 \cdot 1 \ddagger$ & $46 \cdot 1$ & $73 \cdot 7$ & $104 \cdot 1$ & $87 \cdot 1$ & $125 \cdot 2$ \\
\hline Vitamin A (mg) & $1 \cdot 3$ & 0.9 & 1.9 & $152 \cdot 1 \ddagger$ & $111 \cdot 8$ & $218 \cdot 6$ & $116 \cdot 0$ & $99 \cdot 3$ & $141 \cdot 6$ \\
\hline$\beta$-Carotene $(\mu \mathrm{g})$ & 3865.9 & $3444 \cdot 8$ & $5735 \cdot 3$ & - & - & - & $113 \cdot 4$ & $86 \cdot 3$ & $151 \cdot 8$ \\
\hline Vitamin C (mg) & $124 \cdot 4$ & $85 \cdot 6$ & $178 \cdot 4$ & $150 \cdot 2 \ddagger$ & $96 \cdot 5$ & $207 \cdot 5$ & $78 \cdot 8$ & $65 \cdot 8$ & $107 \cdot 5$ \\
\hline Vitamin D ( $\mu \mathrm{g})$ & $1 \cdot 8$ & $1 \cdot 2$ & $2 \cdot 6$ & $8.9 \ddagger$ & $5 \cdot 8$ & $13 \cdot 2$ & $81 \cdot 1$ & $61 \cdot 4$ & $120 \cdot 6$ \\
\hline Vitamin E (mg) & $11 \cdot 2$ & $9 \cdot 0$ & $14 \cdot 4$ & $103 \cdot 9$ & $78 \cdot 2$ & $133 \cdot 7$ & $90 \cdot 1$ & $70 \cdot 0$ & $126 \cdot 2$ \\
\hline Vitamin K $(\mu \mathrm{g})$ & $292 \cdot 3$ & $227 \cdot 2$ & $387 \cdot 0$ & $803 \cdot 4 \ddagger$ & $633 \cdot 4$ & $1080 \cdot 4$ & $120 \cdot 0$ & $100 \cdot 1$ & $135 \cdot 5$ \\
\hline Thiamin (mg) & $1 \cdot 3$ & $1 \cdot 1$ & $1 \cdot 7$ & $125 \cdot 1 \ddagger$ & $102 \cdot 8$ & $154 \cdot 2$ & $81 \cdot 4$ & $64 \cdot 6$ & $111 \cdot 3$ \\
\hline Riboflavin (mg) & 1.5 & $1 \cdot 2$ & $1 \cdot 8$ & $119 \cdot 9 \ddagger$ & $96 \cdot 5$ & $149 \cdot 7$ & $83 \cdot 8$ & $70 \cdot 7$ & $101 \cdot 0$ \\
\hline Niacin $(\mathrm{mg})$ & $25 \cdot 6$ & $21 \cdot 3$ & $31 \cdot 4$ & $196 \cdot 8 \ddagger$ & $162 \cdot 0$ & $234 \cdot 8$ & $99 \cdot 2$ & $76 \cdot 3$ & $116 \cdot 7$ \\
\hline Pantothenic acid (mg) & $4 \cdot 9$ & $4 \cdot 0$ & $6 \cdot 2$ & $97 \cdot 3$ & $79 \cdot 9$ & $123 \cdot 5$ & - & - & - \\
\hline Vitamin $B_{6}(\mathrm{mg})$ & $1 \cdot 7$ & $1 \cdot 4$ & $2 \cdot 1$ & $194 \cdot 9 \ddagger$ & $154 \cdot 4$ & $247 \cdot 7$ & $87 \cdot 1$ & $77 \cdot 8$ & $115 \cdot 2$ \\
\hline Biotin $(\mu \mathrm{g})$ & $43 \cdot 9$ & $35 \cdot 7$ & $56 \cdot 6$ & $205 \cdot 3 \ddagger$ & $160 \cdot 9$ & $261 \cdot 1$ & $82 \cdot 9$ & $70 \cdot 8$ & $108 \cdot 7$ \\
\hline Folate $(\mu \mathrm{g})$ & $217 \cdot 5$ & $170 \cdot 5$ & $269 \cdot 5$ & $61 \cdot 3 \ddagger$ & $47 \cdot 9$ & $77 \cdot 5$ & $91 \cdot 2$ & $67 \cdot 6$ & $105 \cdot 3$ \\
\hline Cobalamin $(\mu \mathrm{g})$ & $4 \cdot 2$ & $3 \cdot 1$ & $5 \cdot 4$ & $219 \cdot 8 \ddagger$ & $161 \cdot 4$ & $284 \cdot 8$ & $87 \cdot 2$ & $73 \cdot 6$ & $115 \cdot 6$ \\
\hline
\end{tabular}

$P_{25}$, 25th percentile; $P_{75}, 75$ th percentile.

${ }^{*}$ From reference 13.

tFrom reference 25 .

¥Wilcoxon signed-rank test, reported intakes $v$. German Dietary Reference Intakes, $P$ value $<0 \cdot 0019$.

meat products as well as sweets, snacks and sweetened beverages consumed by the TEENDIAB children exceeded the recommended proportions of the Optimized Mixed Diet recommendations $(43.9 \% v, 40 \%, P=0.145$ for beverages; $5.4 \%$ v. $2 \%, P<0.001$ for meat and meat products; $10 \cdot 2 \% v .3 \%, P<0 \cdot 001$ for sweets, snacks and sweetened beverages). In contrast, the consumed amounts of vegetables, fruits, carbohydrate-rich foods, milk and dairy products as well as oil, margarine and butter were below the recommended proportions $(7 \cdot 0 \%$ v. $10 \%, P<0.001$ for vegetables; $5.9 \% v .10 \%, P<0.001$ for fruits; $15.0 \% v .16 \%, P<0.001$ for carbohydrate-rich foods; $10.6 \%$ v. $18 \%, P<0.001$ for milk and dairy products; $0.8 \% v .1 \%, P<0.001$ for oil, margarine and butter). Only the consumed amounts of fish and eggs were within the recommended food group proportions of less than $1 \%$ of the total food intake (Table 3 ).

\section{Discussion}

Dietary intake and behaviour is discussed as a potential factor influencing the development of islet autoimmunity and $\mathrm{T}_{1} \mathrm{D}^{(1,3)}$. Little is known about dietary intake and behaviour in children at increased risk of T1D. Here we compared the dietary intake of children participating in the TEENDIAB study with the German Dietary Reference Intakes and intake data of the EsKiMo subjects on the nutrient level and with the Optimized Mixed Diet recommendations on the food level with the following main findings. The TEENDIAB children had intakes significantly below the German Dietary Reference Intakes only for three micronutrients, which were folate, iodine and vitamin D. They highly exceeded the reference intake values for vitamin $\mathrm{K}, \mathrm{Na}$ and protein. Comparing a subsample of the TEENDIAB study with the EsKiMo cohort 
Table 3 Daily food consumption in food groups according to the Optimized Mixed Diet recommendations, expressed as weight consumed and percentage of the total weight: TEENDIAB children, Germany, February 2009-January 2012

\begin{tabular}{|c|c|c|c|c|c|c|c|}
\hline \multirow[b]{4}{*}{ Food group } & & & & \multicolumn{4}{|c|}{ Food group proportions } \\
\hline & \multicolumn{3}{|c|}{ TEENDIAB intake data } & \multicolumn{3}{|c|}{ TEENDIAB intake data } & \multirow{2}{*}{$\frac{\text { Optimized Mixed Die }}{\% \text { of total weight }}$} \\
\hline & \multicolumn{3}{|c|}{ Absolute amount, $\mathrm{g}$} & \multicolumn{3}{|c|}{$\%$ of total weight } & \\
\hline & Median & $\mathrm{P}_{25}$ & $\mathrm{P}_{75}$ & Median & $\mathrm{P}_{25}$ & $\mathrm{P}_{75}$ & Mean \\
\hline Beverages & $1094 \cdot 3$ & $768 \cdot 8$ & $1561 \cdot 7$ & 43.9 & $30 \cdot 9$ & $62 \cdot 7$ & 40 \\
\hline Vegetables & $174 \cdot 8$ & $88 \cdot 1$ & $272 \cdot 5$ & $7 \cdot 0 t$ & 3.5 & $10 \cdot 9$ & 10 \\
\hline Fruits & $146 \cdot 3$ & $67 \cdot 1$ & $259 \cdot 3$ & $5 \cdot 9 t$ & $2 \cdot 7$ & $10 \cdot 4$ & 10 \\
\hline Carbohydrate-rich foods & $375 \cdot 0$ & $295 \cdot 8$ & $454 \cdot 5$ & $15 \cdot 1 \dagger$ & 11.9 & $18 \cdot 3$ & 16 \\
\hline Milk and dairy products & $263 \cdot 9$ & $153 \cdot 1$ & $400 \cdot 4$ & $10 \cdot 6+$ & $6 \cdot 1$ & $16 \cdot 1$ & 18 \\
\hline Meat and meat products & $133 \cdot 6$ & $88 \cdot 4$ & $177 \cdot 3$ & $5 \cdot 4 \dagger$ & 3.5 & $7 \cdot 1$ & 2 \\
\hline Eggs & $20 \cdot 9$ & $12 \cdot 2$ & $34 \cdot 0$ & $0 \cdot 8$ & 0.5 & $1 \cdot 4$ & $<1$ \\
\hline Oil, margarine and butter & $19 \cdot 3$ & $15 \cdot 6$ & $26 \cdot 1$ & $0.8 \dagger$ & 0.6 & $1 \cdot 1$ & 1 \\
\hline Fish & $8 \cdot 3$ & 0.0 & $17 \cdot 5$ & 0.3 & 0.0 & 0.7 & $<1$ \\
\hline Sweets, snacks and sweetened beverages & 253.5 & $107 \cdot 9$ & $543 \cdot 8$ & $10 \cdot 2+$ & $4 \cdot 3$ & $21 \cdot 8$ & 3 \\
\hline
\end{tabular}

*From reference 14 .

tWilcoxon signed-rank test, reported intakes $v$. Optimized Mixed Diet recommendations, $P$ value $<0 \cdot 005$.

assessed with the same dietary assessment method revealed similar intakes. Compared with the Optimized Mixed Diet recommendations, most critically it has to be considered that the TEENDIAB children exceeded the recommendations for meat and meat products as well as for sweets, snacks and sweetened beverages and that they were below the recommendations for fruits, vegetables and carbohydrate-rich foods.

To our knowledge, the present study is the first one which assessed the dietary intake in adolescents at increased risk of $\mathrm{T} 1 \mathrm{D}$ and therefore opens up the opportunity to evaluate the adherence of this cohort to current recommendations. Using a diet history interview provided detailed information on the dietary intake and behaviour of the children with the possibility to calculate food and nutrient intakes.

The macronutrient intake of the TEENDIAB children expressed as a percentage of the total energy intake was $52.0 \%$ for carbohydrates, $32.6 \%$ for fat and $14.3 \%$ for protein, and was therefore within the range of the German Dietary Reference Intakes. The recommended macronutrient distribution ranges as a percentage of total energy are $>50 \%$ for carbohydrates, $30-35 \%$ for fat and $10-15 \%$ for protein ${ }^{(13)}$. However, the fatty acid distribution was not desirable for the cohort. Assuming the reference values for adults as being valid also for children, SFA and non-SFA (MUFA and PUFA) are supposed to be in the ratio 1:2 with SFA accounting for a maximum of $10 \%$ of total energy and with PUFA accounting for $7-10 \%$ of total energy ${ }^{(13,24)}$. The intake of $13.9 \%$ of energy from SFA of the TEENDIAB children exceeded the reference value, whereas the intake of $4 \cdot 6 \%$ of energy from PUFA was below the reference of the German Dietary Reference Intakes ${ }^{(15)}$. These dietary patterns were found very similarly within the EsKiMo cohort ${ }^{(24,25)}$.

Although the contribution of protein of total energy intake was within the range of the reference values, the absolute protein intake of the TEENDIAB children exceeded the German Dietary Reference Intake about 1.5-fold. This observation might be reflected by the fact that the consumption of meat and meat products was also highly above the recommendations. According to present knowledge, there is no direct evidence of a protein intake above the recommendations being harmful for healthy individuals. Nevertheless, the intake of animal protein is generally connected with a concurrent intake of fat and cholesterol $^{(13)}$. The cholesterol intake of the TEENDIAB children actually also exceeded the recommendation by $86 \%$. Furthermore, a high protein intake is discussed to be a risk factor for developing T1D, especially in early childhood diet $^{(1,8)}$ and maybe also during early puberty ${ }^{(11)}$.

The $\mathrm{Na}$ intake of the TEENDIAB children reached a median value of $546 \%$ of the German Dietary Reference Intakes. As $\mathrm{Na}$ consumption through extra salting could not be recorded with DISHES Junior ${ }^{(25)}$, the actual median $\mathrm{Na}$ intake of the children might be even higher. The urinary $\mathrm{Na}$ excretion increases with an increased $\mathrm{Na}$ intake, but additionally triggers an increased urinary $\mathrm{Ca}$ excretion which might have serious consequences as an adequate $\mathrm{Ca}$ supply is especially essential during periods of bone growth $^{(13)}$. Vitamin $\mathrm{K}$ exceeded the recommendations by about seven times. However, there is no upper intake level for vitamin $\mathrm{K}$ assigned by the European Food Safety Authority ${ }^{(13)}$.

The intake of vitamin D within the TEENDIAB study was considerably below the reference value, which is in line with the finding for the EsKiMo children ${ }^{(25)}$. However, the TEENDIAB children had a median absolute daily intake of $1.8 \mu \mathrm{g}$ vitamin $\mathrm{D}$, which is within the range of a feasible dietary intake from common foods of $1-2 \mu \mathrm{g} / \mathrm{d}^{(13)}$. Since the TEENDIAB study does not assess nutritional supplements, there was no possibility to evaluate the implementation of the German Dietary Reference Intakes to complement the dietary intake of 
vitamin D by supplementation if the exposure to sunlight is not sufficient for endogenous vitamin D synthesis. The role of vitamin D in the development of T1D is conversely discussed, but there is no clear evidence that vitamin D intake is associated with T1D risk ${ }^{(1,8)}$. The result for iodine within the TEENDIAB cohort is again consistent with the observation from the EsKiMo study, since these children also have a median intake of only $50 \%$ of the respective reference value ${ }^{(24,25)}$. As the intake of this mineral is assumed to be actually above the recorded amount due to difficulties in capturing consumption in the form of iodized table salt used in the food industry and in the household setting, the low intake probably does not have to be seen as alarming ${ }^{(25)}$. The third micronutrient for which the TEENDIAB children had an intake below the German Dietary Reference Intakes was folate. The assessment of the folate intake within the EsKiMo study revealed that these children were also undersupplied in respect to the reference value ${ }^{(24)}$.

The assessment of the TEENDIAB intake data on the food level showed that the food intake of the TEENDIAB children was not well balanced under general disease preventive aspects. According to the recommendations of the Optimized Mixed Diet, the consumption of meat and meat products as well as of sweets, snacks and sweetened beverages needs to be decreased in both cohorts, whereas the consumption of plant-based foods needs to be increased ${ }^{(24)}$. In contrast to the EsKiMo subjects, the TEENDIAB children additionally showed an intake of milk and dairy products which was below the recommendations of the Optimized Mixed Diet. The finding of an intake below the recommendations for vegetables and fruits and above for sweets, snacks and sweetened beverages could also be seen within the DONALD (Dortmund Nutritional and Anthropometric Longitudinally Designed) Study, conducted by the authors of the Optimized Mixed Diet recommendations ${ }^{(26,27)}$. Under T1D-related aspects, a lower intake of carbohydrate-rich foods, fruits, vegetables and dairy products may be positive as high intakes of these foods were hypothesized to increase the risk of T1D in children and adolescents ${ }^{(4,9,11)}$. A high intake of carbohydrates, especially in the form of disaccharides and sucrose $^{(12)}$, as well as of meat and meat products ${ }^{(10)}$ was associated with the development of T1D.

There are some limitations of the current analysis. First of all, it is an interim analysis of the dietary behaviour of the TEENDIAB participants and therefore only included the data of 268 children at baseline. In total, a number of 1500 children are planned for the study, providing the opportunity to confirm these results after completion of the whole study. Furthermore, as the TEENDIAB study aims to investigate the natural course of the development of islet autoimmunity and T1D during puberty ${ }^{(2)}$, it does not provide healthy controls. However, comparing the intake data of the children at increased risk of T1D with those of non-risk children was important to evaluate the dietary behaviour more precisely. Therefore, we evaluated the diet of the TEENDIAB children against the data of the EsKiMo subjects. As there was a methodological difference in the assessment of the dietary intake for the children aged 8-11 years between both cohorts, we conducted this comparison only in a small sub-sample of the TEENDIAB participants. Nevertheless, we considered DISHES Junior as being most suitable for assessing the diet of children aged 8-14 years with one harmonized method, since there is no indirect dietary assessment method which is able to report the true intake of a person $^{(27,28)}$. The retrospective documentation of dietary intake used within DISHES Junior relies heavily on children's self-reports. The children need very good memory and the ability to correctly estimate consumed portion sizes $^{(28)}$. Therefore, parents were asked to serve as proxy respondents, especially for younger children. Another issue which is important to note is that the preliminary TEENDIAB cohort included in the current analysis revealed a selection bias towards a higher socio-economic background of the children. This might be due to higher engagement and health interest with an increasing socioeconomic status. This bias needs to be considered when evaluating the diet of the children since several studies have shown that dietary quality follows a social gradient, i.e. higher social status is associated with healthier diet ${ }^{(29,30)}$. Furthermore, as the TEENDIAB children all have at least one first-degree relative with T1D, the diet within the family and of the participants could be different from that of children from a representative sample of the EsKiMo study. However, the comparison against the intake data of the EsKiMo children did not provide much evidence for this assumption.

\section{Conclusion}

Children participating in the TEENDIAB study were sufficiently provided with macronutrients and micronutrients, with the exception of vitamin D, iodine and folate for which their intakes were considerably below the German Dietary Reference Intakes. However, their vitamin $\mathrm{K}$, Na and protein intakes were considerably above. Compared with a control cohort of healthy children and adolescents from the EsKiMo study, the nutrient intakes of the TEENDIAB children were very similar. Furthermore, the TEENDIAB children consumed too much meat and meat products as well as sweets, snacks and sweetened beverages, which could be also observed within two other cohorts of German children and adolescents. Thus, being at increased risk of T1D seems not to improve or worsen the main dietary patterns of the TEENDIAB children. In future, the TEENDIAB study aims to investigate the impact of the dietary intake and behaviour as well as their interactions with other exogenous and endogenous factors on the development of islet autoimmunity and T1D during puberty. 


\section{Acknowledgements}

Sources of funding: The TEENDIAB study is supported by Kompetenznetz Diabetes mellitus (Competence Network for Diabetes mellitus) funded by the Federal Ministry of Education and Research (FKZ 01GI0805). Kompetenznetz Diabetes mellitus had no role in the design, analysis or writing of this article. Conflicts of interest: The authors declare that they have no conflict of interest. Authorship: K.S.W. researched data, performed statistical analysis, interpreted the results and wrote the manuscript. F.H., J.R., B.A., A.W. and C.R. acquired data and reviewed/ edited the manuscript. O.K. is the Co-Investigator of the TEENDIAB study and reviewed/edited the manuscript. A.-G.Z. is the Principal Investigator of the TEENDIAB study, designed the study, reviewed the data, contributed to the statistical analysis, was involved in the interpretation of the results and wrote the manuscript. C.W. researched data, contributed to the statistical analysis, was involved in the interpretation of the results and wrote the manuscript. Each author has seen and approved the contents of the submitted manuscript. Acknowledgements: The authors thank Simone Schneider, Kerstin Remus, Sarah Bläsig, Evelin Sadeghian and Anika Bokelmann for data collection and expert technical assistance. They wish to thank all families participating in the TEENDIAB study and also all paediatricians, diabetologists and family doctors in Germany for recruitment and continuous support.

\section{References}

1. Thrower SL \& Bingley PJ (2011) Prevention of type 1 diabetes. Br Med Bull 99, 73-88.

2. Ziegler AG, Meier-Stiegen F, Winkler C et al. (2012) Prospective evaluation of risk factors for the development of islet autoimmunity and type 1 diabetes during puberty TEENDIAB: study design. Pediatr Diabetes 13, 419-424.

3. Atkinson MA \& Eisenbarth GS (2001) Type 1 diabetes: new perspectives on disease pathogenesis and treatment. Lancet 358, 221-229.

4. Thorsdottir I \& Ramel A (2003) Dietary intake of 10- to 16-year-old children and adolescents in central and northern Europe and association with the incidence of type 1 diabetes. Ann Nutr Metab 47, 267-275.

5. Norris JM, Barriga K, Klingensmith G et al. (2003) Timing of initial cereal exposure in infancy and risk of islet autoimmunity. JAMA 290, 1713-1720.

6. Virtanen SM, Nevalainen J, Kronberg-Kippila C et al. (2012) Food consumption and advanced $\beta$ cell autoimmunity in young children with HLA-conferred susceptibility to type 1 diabetes: a nested case-control design. Am J Clin Nutr $\mathbf{9 5}$, 471-478.

7. Ziegler A, Schmid S, Huber D et al. (2003) Early infant feeding and risk of developing type 1 diabetes-associated autoantibodies. JAMA 290, 1721-1728.

8. Knip M, Virtanen SM \& Akerblom HK (2010) Infant feeding and the risk of type 1 diabetes. Am J Clin Nutr 91, 1506-1513.

9. Virtanen SM \& Knip M (2003) Nutritional risk predictors of $\beta$ cell autoimmunity and type 1 diabetes at a young age. Am J Clin Nutr 78, 1053-1067.
10. Muntoni S, Cocco P, Aru G et al. (2000) Nutritional factors and worldwide incidence of childhood type 1 diabetes. $\mathrm{Am}$ J Clin Nutr 71, 1525-1529.

11. Dahlquist GG, Blom LG, Persson LA et al. (1990) Dietary factors and the risk of developing insulin dependent diabetes in childhood. BMJ 300, 1302-1306.

12. Pundziute-Lycka A, Persson LA, Cedermark G et al. (2004) Diet, growth, and the risk for type 1 diabetes in childhood. A matched case-referent study. Diabetes Care 27, 2784-2789.

13. Deutsche Gesellschaft für Ernährung, Österreichische Gesellschaft für Ernährung, Schweizerische Gesellschaft für Ernährungsforschung et al. (editors) (2008) Referenzwerte für die Nährstoffzufubr. Neustadt an der Weinstraße: Neuer Umschau Buchverlag.

14. Kersting M, Alexy U \& Clausen K (2005) Using the concept of food based dietary guidelines to develop an Optimized Mixed Diet (OMD) for German children and adolescents. J Pediatr Gastroenterol Nutr 40, 301-308.

15. Kersting M \& Alexy U (2009) Empfehlungen für die Ernäbrung von Kindern und Jugendlichen. Die Optimierte Mischkost optimiX. Lüdinghausen: Druck- und Medienhaus Rademann.

16. Mensink GB, Bauch A, Vohmann C et al. (2007) EsKiMo the nutrition module in the German Health Interview and Examination Survey for Children and Adolescents (KiGGS). Bundesgesundheitsblatt Gesundheitsforschung Gesundbeitsschutz 50, 902-908.

17. Kronmeyer-Hauschild K, Wabitsch M, Kunze D et al. (2001) Perzentile für den Body-mass-Index für das Kindes- und Jugendalter unter Heranziehung verschiedener deutscher Stichproben. Monatsschr Kinderbeilkd 149, 807-818

18. Kurth B, Kamtsiuris P, Holling H et al. (2008) The challenge of comprehensively mapping children's health in a nationwide health survey: design of the German KiGGS-Study. BMC Public Health 8, 196-204.

19. Stahl A, Vohmann C, Richter A et al. (2009) Changes in food and nutrient intake of 6- to 17-year-old Germans between the 1980s and 2006. Public Health Nutr 12, 1912-1923.

20. Mensink GBM, Haftenberger M \& Thamm M (2001) Validity of DISHES 98, a computerised dietary history interview: energy and macronutrient intake. Eur J Clin Nutr 55, 409-417.

21. van Kappel AL, Amoyel J, Slimani N et al. (1994) EPIC-SOFT Picture Book for Estimation of Food Portion Sizes. Lyon: IARC.

22. Alexy U, Clausen K \& Kersting M (2008) Die Ernährung gesunder Kinder und Jugendlicher nach dem Konzept der Optimierten Mischkost. Ernahrungs Umschau 3, issue 8, 168-177.

23. Kurth B \& Schaffrath Rosario A (2007) The prevalence of overweight and obese children and adolescents living in Germany. Results of the German Health Interview and Examination Survey for Children and Adolescents (KiGGS). Bundesgesundheitsblatt Gesundheitsforschung Gesundheitsschutz 50, 736-743.

24. Stahl A (2008) Lebensmittelverzehr und Nährstoffzufuhr bei Kindern der deutschlandweiten EsKiMo-Studie unter besondere Berücksichtigung des Sozialstatus. PhD Thesis, Universität Paderborn.

25. Mensink GBM, Heseker H, Richter A et al. (2007) Ernährungsstudie als KiGGS-Modul (EsKiMo) - Forschungsbericht. http://www.bmelv.de/SharedDocs/Downloads/ Ernaehrung/EsKiMoStudie.pdf?__blob=publicationFile (accessed March 2013).

26. Kersting M, Alexy U, Kroke A et al. (2004) Nutrition of children and adolescents. Results of the DONALD Study. Bundesgesundheitsblatt Gesundheitsforschung Gesundbeitsschutz 47, 213-218. 
27. Burrows TL, Martin RJ \& Collins CE (2010) A systematic review of the validity of dietary assessment methods in children when compared with the method of doubly labeled water. J Am Diet Assoc 110, 1501-1510.

28. Livingstone MB \& Robson PJ (2000) Measurement of dietary intake in children. Proc Nutr Soc 59, 279-293.

29. Eagle TF, Sheetz A, Gurm R et al. (2012) Understanding childhood obesity in America: linkages between household income, community resources, and children's behaviors. Am Heart J 163, 836-843.
30. Drewnowski A (2009) Obesity, diets, and social inequalities. Nutr Rev 67, Suppl. 1, 36-39.

31. Korsten-Reck U, Widhalm K, Berg A et al. (2011) Leitlinien. Verabschiedet auf der Konsensus-Konferenz der AGA am 08.10.2011. Arbeitsgemeinschaft Adipositas im Kindesund Jugendalter der Deutschen Adipositas-Gesellschaft, Mitglied im Konvent für fachliche Zusammenarbeit der Deutschen Gesellschaft für Kinderheilkunde und Jugendmedizin. http://www.adipositasgesellschaft.de/fileadmin/ PDF/Leitlinien/AGA_S2_Leitlinie.pdf (accessed January 2013). 